Nevada

Environmental

Restoration

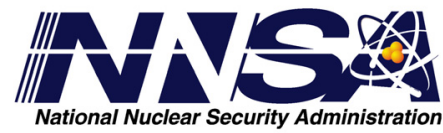

Project

\title{
Addendum to the Closure Report for Corrective Action Unit 335: Area 6 Injection Well and Drain Pit Nevada Test Site, Nevada
}

Controlled Copy No::

Revision No.: 0

October 2008

Approved for public release; further dissemination unlimited.

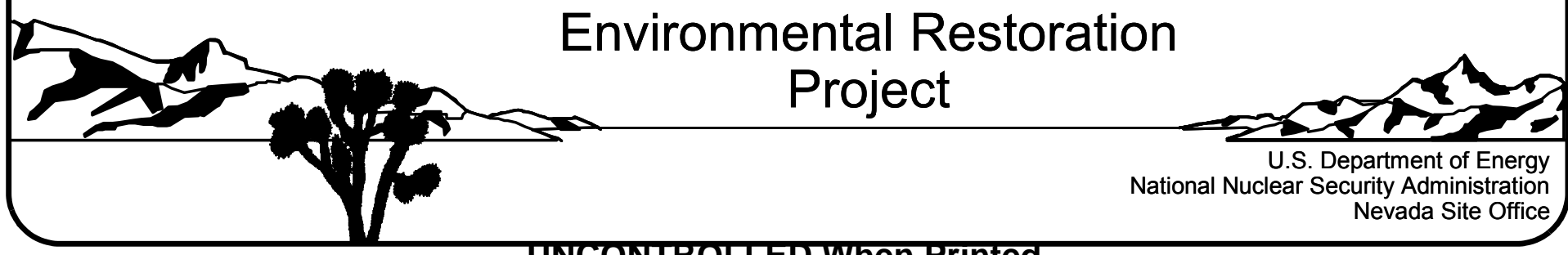


Available for public sale, in paper, from:

U.S. Department of Commerce

National Technical Information Service

5285 Port Royal Road

Springfield, VA 22161

Phone: 800.553 .6847

Fax: 703.605.6900

Email: orders@ntis.gov

Online ordering: http://www.ntis.gov/ordering.htm

Available electronically at $\underline{h t p: / / w w w . o s t i . g o v / b r i d g e ~}$

Available for a processing fee to U.S. Department of Energy and its contractors, in paper, from:

U.S. Department of Energy

Office of Scientific and Technical Information

P.O. Box 62

Oak Ridge, TN 37831-0062

Phone: 865.576 .8401

Fax: 865.576.5728

Email: reports@adonis.osti.gov

Reference herein to any specific commercial product, process, or service by trade name, trademark, manufacturer, or otherwise, does not necessarily constitute or imply its endorsement, recommendation, or favoring by the United States Government or any agency thereof or its contractors or subcontractors. 


\title{
ADDENDUM TO THE CLOSURE REPORT FOR CORRECTIVE ACTION UNIT 335: AREA 6 INJECTION WELL AND DRAIN PIT NEVADA TEST SITE, NEVADA
}

\author{
U.S. Department of Energy \\ National Nuclear Security Administration \\ Nevada Site Office \\ Las Vegas, Nevada
}

Controlled Copy No.:

Revision No.: 0

October 2008

Approved for public release; further dissemination unlimited. 


\section{Addendum to the Closure Report for Removal of the Use Restriction}

This document constitutes an addendum to the June 2003, Closure Report for Corrective Action Unit 335: Area 6 Injection Well and Drain Pit as described in the document Recommendations and Justifications for Modifications for Use Restrictions Established under the U.S. Department of Energy, National Nuclear Security Administration Nevada Site Office Federal Facility Agreement and Consent Order (UR Modification document) dated February 2008. The UR Modification document was approved by NDEP on February 26, 2008. The approval of the UR Modification document constituted approval of each of the recommended UR modifications. In conformance with the UR Modification document, this addendum consists of:

- This cover page that refers the reader to the UR Modification document for additional information

- The cover and signature pages of the UR Modification document

- The NDEP approval letter

- The corresponding section of the UR Modification document

This addendum provides the documentation justifying the cancellation of the URs for:

- CAS 06-20-02, 20-inch Cased Hole

- CAS 06-23-03, Drain Pit

These URs were established as part of Federal Facility Agreement and Consent Order (FFACO) corrective actions and were based on the presence of contaminants at concentrations greater than the action levels established at the time of the initial investigation (FFACO, 1996; as amended August 2006).

Since these URs were established, practices and procedures relating to the implementation of risk-based corrective actions (RBCA) have changed. Therefore, these URs were re-evaluated against the current RBCA criteria as defined in the Industrial Sites Project Establishment of Final Action Levels (NNSA/NSO, 2006c). This re-evaluation consisted of comparing the original data (used to define the need for the URs) to risk-based final action levels (FALs) developed using the current Industrial Sites RBCA process.

The re-evaluation resulted in a recommendation to remove these URs because contamination is not present at these sites above the risk-based FALs. Requirements for inspecting and maintaining these URs will be canceled, and the postings and signage at each site will be removed. Fencing and posting may be present at these sites that are unrelated to the FFACO URs such as for radiological control purposes as required by the NV/YMP Radiological Control Manual (NNSA/NSO, 2004f). This modification will not affect or modify any non-FFACO requirements for fencing, posting, or monitoring at these sites. 
Nevada

Environmental

Restoration

Project

Recommendations and Justifications for Modifications for Use Restrictions Established under the U.S. Department of Energy, National Nuclear Security Administration Nevada Site Office

Federal Facility Agreement and Consent Order

Controlled Copy No.:

Revision No.: 0

February 2008

Approved for public release; further dissemination unlimited.

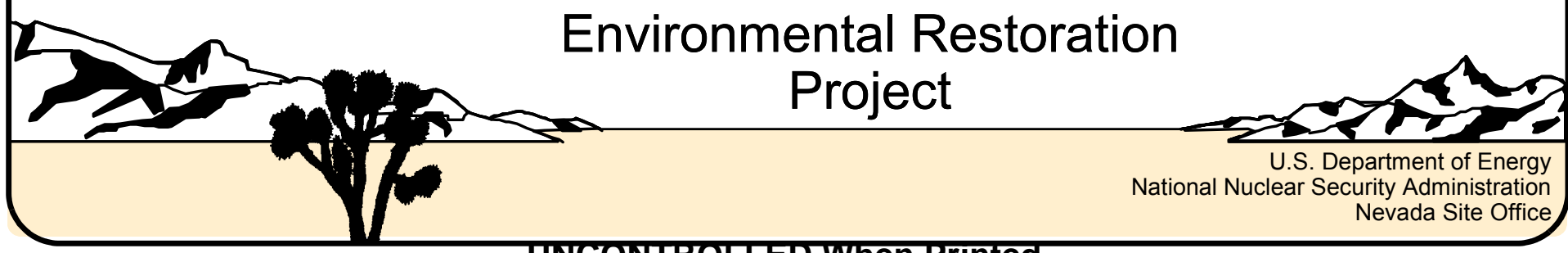


Recommendations and Justifications for Modifications for Use Restrictions Established under the U.S. Department of Energy, National Nuclear Security Administration Nevada Site Office Federal Facility Agreement and Consent Order

Approved by: /s/ Kevin J. Cabble

Date: $02 / 05 / 2008$

Kevin J. Cabble

Federal Sub-Project Director

Industrial Sites Sub-Project

Approved by:

/s/ John B. Jones

Date: $02 / 04 / 2008$

John B. Jones

Acting Federal Project Director

Environmental Restoration Project 
February 26, 2008

John B. Jones

Acting Federal Project Director

Environmental Restoration Project

National Nuclear Security Administration

Nevada Site Office

P. O. Box 98518

Las Vegas, NV 89193-8518

RE: Approval of Recommendations and Justifications for Modifications for Use Restrictions

Established under the U.S. Department of Energy, National Nuclear Security Administration, Nevada Site Office Federal Facility Agreement and Consent Order

Dear Mr. Jones:

The Nevada Division of Environmental Protection, Bureau of Federal Facilities (NDEP) staff has received and reviewed the February 2008 final report for Recommendations and Justifications for Modifications for Use Restrictions Established under the U.S. Department of Energy, National Nuclear Security Administration, Nevada Site Office. The NDEP approves the requested changes to the previously agreed upon use restrictions for those Corrective Action Sites (CASs) as described in the report.

Address any questions regarding this matter to either Ted Zaferatos at (702) 486-2850, ext. 234 , or me at (702) 486-2850, ext. 231.

Sincerely

\section{/s/ Tim Murphy}

\section{T.H. Murphy}

Chief

Bureau of Federal Facilities

$\mathrm{TZ}$

cc: $\quad$ E.F. DiSanza, WMP, NNSA/NSO

FFACO Group, PSG, NNSAINSO, Las Vegas, NV

David C. Loewer, DTRAVCXT1, M/S 645, Mercury, NV

W.R. Griffin, SNJV/DTRA, M/S 645, Mercury, NV

T.A. Thiele, NSTec, Las Vegas, NV

R.F. Boehlecke, SNJV, Las Vegas, NV

K. J. Cabble, ERP, NNSANSO, Las Vegas, NV

John Wong. Jeff MacDougall, Dennis Nicodemus, NDEP Las Vegas, NV 


\subsection{CAU 335, CAS 06-20-02 - 20-inch Cased Hole}

\subsection{CAS Description}

The Cased Hole is approximately $10 \mathrm{ft}$ from the northeast corner of Building 6-388 in the southern portion of the Well 3 Yard. The site was used for the disposal of used motor oil, wastewater, and debris. On October 2, 1990, the Cased Hole was inspected by Reynolds Electrical \& Engineering Co., Inc., and noted to be a 20 -in. diameter steel casing that rises approximately $2 \mathrm{ft}$ above grade. Used motor oil, wastewater, and solid debris were removed from the casing (DOE/NV, 2000c).

The casing was excavated with a backhoe on July 25,1991 . During excavation, the surface soil surrounding the casing was noted to be contaminated. The Cased Hole was then backfilled, though it is unknown when this occurred or what material was used for backfill. The site is currently described as a 5-ft-diameter, 3-in.-high mound of soil, presumably at the former location of the Cased Hole (DOE/NV, 2000c).

\subsection{Current Use Restriction Description}

The future use of any land related to this CAS is restricted from any DOE or Air Force activity that may alter or modify the containment control, as approved by the state and identified in the CAU CR or other CAU documentation, unless appropriate concurrence is obtained in advance. The UR covers two land areas: (1) a large area south of Road 6-06, and (2) a small area immediately north of Road 6-06. T-posts with attached warning signs were placed along the perimeter of the areas approximately every $100 \mathrm{ft}$. All signs warn of the presence of TPH-contaminated soil and lists contact information. Post-closure monitoring consists of an annual sign inspection to verify that they are in place and readable, and that URs are maintained (NNSA/NSO, 2003b).

\subsection{Basis for Current Use Restriction}

Samples were analyzed for total VOCs, total SVOCs, TPH (DRO), and total RCRA metals. Except for arsenic, TPH (DRO) was the only COPC detected above PALs in the remaining material (following remediation). Arsenic was detected above the PAL of $2.7 \mathrm{mg} / \mathrm{kg}$ in all 12 samples taken at Cased Hole. The concentrations of arsenic above the PAL of $2.7 \mathrm{mg} / \mathrm{kg}$ were within the range considered representative of ambient conditions at the site. Therefore, arsenic is not considered to be a basis for this UR. Total petroleum hydrocarbons (DRO) were 
detected at concentrations exceeding the PAL of $100 \mathrm{mg} / \mathrm{kg}$ in 16 of 93 soil samples collected at this CAS. The vertical extent of TPH (DRO) contamination did not exceed $0.5 \mathrm{ft}$ bgs except for three anomalous sample locations at the Cased Hole where TPH was found at up to $5 \mathrm{ft}$ bgs. The lateral extent of TPH (DRO) contamination at the Cased Hole was generally confined to the north by Road 6-06, to the east by the Mercury Highway, and to the west by the boundaries of the drilling supply storage area. No VOCs or SVOCs were detected above PALs (NNSA/NV, 2001c).

Table 11-1 contains analytical results of all COCs at CAS 06-20-02 that are the basis for the current UR. The sample matrix for all samples is soil.

Table 11-1

Sample Results for COCs at CAS 06-20-02 Used To Establish Current Use Restriction

\begin{tabular}{|c|c|c|c|c|}
\hline \multirow[b]{2}{*}{ Investigation } & \multirow[b]{2}{*}{ Sample Location } & \multirow[b]{2}{*}{ Sample ID } & \multirow{2}{*}{$\begin{array}{l}\text { Depth } \\
\text { (ft bgs) }\end{array}$} & \multirow{2}{*}{$\begin{array}{c}\text { TPH (DRO) } \\
\text { PAL } \\
100 \mathrm{mg} / \mathrm{kg}\end{array}$} \\
\hline & & & & \\
\hline \multirow{3}{*}{ January 2001} & $\begin{array}{l}\text { Boring } \mathrm{CH} 01 \text { (former } \\
\text { location of steel casing }\end{array}$ & $\mathrm{CH} 0101$ & $0.0-0.5$ & 1,100 \\
\hline & Boring $\mathrm{CH} 02$ & $\mathrm{CH} 0202$ & $3-5$ & $180(\mathrm{~J})$ \\
\hline & Boring $\mathrm{CHO} 3$ & $\mathrm{CH} 0301$ & $0.0-0.5$ & $840(\mathrm{~J})$ \\
\hline \multirow{13}{*}{ May 2001} & \multirow{2}{*}{ Auger CHN01 } & CHN01A & $0.0-0.5$ & 450 \\
\hline & & CHN01X & $0.0-0.5$ & 480 \\
\hline & Auger $\mathrm{CHNO2}$ & $\mathrm{CHN} 02 \mathrm{~A}$ & $0.0-0.5$ & 170 \\
\hline & Auger $\mathrm{CHSO2}$ & $\mathrm{CHS02A}$ & $0.0-0.5$ & 490 \\
\hline & Auger CHE01 & CHE01A & $0.0-0.5$ & 580 \\
\hline & Auger CHE04 & CHE04A & $0.0-0.5$ & 140 \\
\hline & \multirow{2}{*}{ Auger CHW02 } & CHW02A & $0.0-0.5$ & 1,700 \\
\hline & & CHW02B & $0.5-2$ & 120 \\
\hline & \multirow{2}{*}{ Auger CHW03 } & CHW03A & $0.0-0.5$ & $110(\mathrm{~J})$ \\
\hline & & CHW03X & $0.0-0.5$ & 110 \\
\hline & \multirow{3}{*}{ Auger CHW04 } & CHW04A & $0.0-0.5$ & $3,100(\mathrm{~J})$ \\
\hline & & CHW04C & $2-3$ & 690 \\
\hline & & CHW04D & $3-4$ & 250 \\
\hline
\end{tabular}

bgs $=$ Below ground surface

$\mathrm{DRO}=$ Diesel-range organics

$\mathrm{mg} / \mathrm{kg}=$ Milligrams per kilogram

$\mathrm{ft}=$ Foot

$\mathrm{PAL}=$ Preliminary action level

ID = Identification

$\mathrm{TPH}=$ Total petroleum hydrocarbons

$\mathrm{J}=$ Estimated value 


\subsection{Basis for Use Restriction Modification}

The revised FALs associated with the TPH contamination were established based on the PALs of hazardous constituents of TPH diesel as described in Section 2.2.2. Hazardous constituents of TPH diesel were not detected in any of the samples at concentrations greater than their respective PALs (NNSA/NV, 2001c). Therefore, no contaminants are present at this site in concentrations exceeding the revised FALs, and all revised FALs were established at the PAL concentrations.

\subsection{Proposed Modification}

Remove the FFACO UR, associated fencing and postings, and inspection and maintenance requirements from this site. 


\subsection{CAU 335, CAS 06-23-03 - Drain Pit}

\subsection{CAS Description}

The Drain Pit is located in the northern section of the Well 3 Yard, approximately $165 \mathrm{ft}$ north of Road 6-06. It was used to receive effluent from truck washing facilities in the Well 3 Yard. The Drain Pit was operational from 1963 through about 1991, a time span roughly concurrent with underground device testing at the NTS. Cement trucks and geophysical logging trucks were washed in the Well 3 Yard, using two portable steam cleaners. The Drain Pit is oblong-shaped and measures 37 by $65 \mathrm{ft}$ with a maximum depth of about $6 \mathrm{ft}$ at its southeast end. Three drain pipes extend from the north wall of the pit: a pair of 2.5-in.-diameter steel pipes, and a single 5-in.-diameter plastic pipe (DOE/NV, 2000c).

\subsection{Current Use Restriction Description}

The future use of any land related to this CAS is restricted from any DOE or Air Force activity that may alter or modify the containment control, as approved by the state and identified in the CAU CR or other CAU documentation, unless appropriate concurrence is obtained in advance. T-posts with attached warning signs were placed every $100 \mathrm{ft}$ along the perimeter of the area identified in the NDEP-approved CADD (NNSA/NV, 2001c). All signs warn of the presence of TPH contaminated soil, list contact information, and face out away from the restricted area. Warning signs were placed at the four corners and at the midpoint of each side of the area. Post-closure monitoring consists of annual visual inspection of the signs to verify that they are in place and readable, and that URs are maintained (NNSA/NSO, 2003b).

\subsection{Basis for Current Use Restriction}

Samples were analyzed for total VOCs, total SVOCs, TPH (DRO), total RCRA metals, TPH (GRO), ethylene glycol monobutyl ether, PCBs, isotopic $\mathrm{U}$, isotopic $\mathrm{Pu}$, and Sr-90. Total petroleum hydrocarbons (DRO) and arsenic were the only COPCs detected above PALs. Arsenic was detected above the PAL of $2.7 \mathrm{mg} / \mathrm{kg}$ in 27 of 27 samples. The concentrations of arsenic above the PAL of $2.7 \mathrm{mg} / \mathrm{kg}$ were within the range considered representative of ambient conditions at the site. Therefore, arsenic is not considered to be a basis for this UR. Total petroleum hydrocarbons (DRO) were detected at concentrations exceeding the PAL of $100 \mathrm{mg} / \mathrm{kg}$ in 16 of 50 soil samples collected from the Drain Pit. The vertical extent of TPH (DRO) contamination did not exceed $2 \mathrm{ft}$ bgs. The lateral extent of TPH (DRO) contamination at the Drain Pit investigation area was generally confined to the east by the Birdwell Building, to 
the west by a large concrete pad, and to the south by Road 6-06. Contamination was not found north of the Drain Pit. No VOCs or SVOCs were detected above PALs (NNSA/NV, 2001c).

Table 12-1 contains analytical results of all COCs at CAS 06-23-03 that are the basis for the current UR. The sample matrix for all samples is soil.

Table 12-1

Sample Results for COCs at CAS 06-23-03 Used To Establish Current Use Restriction

\begin{tabular}{|c|c|c|c|c|}
\hline \multirow{2}{*}{ Investigation } & \multirow[b]{2}{*}{ Sample Location } & \multirow[b]{2}{*}{ Sample ID } & \multirow{2}{*}{$\begin{array}{l}\text { Depth } \\
\text { (ft bgs) }\end{array}$} & \multirow{2}{*}{$\begin{array}{c}\text { TPH (DRO) } \\
\text { PAL } \\
100 \mathrm{mg} / \mathrm{kg}\end{array}$} \\
\hline & & & & \\
\hline \multirow{11}{*}{ January 2001} & Boring DP02 (Outside Drain Pit) & DP0202 & $0.5-2$ & 660 \\
\hline & Boring DP03 (Outside Drain Pit) & DP0302 & $0.5-2$ & 360 \\
\hline & Boring DP04 (Outside Drain Pit) & DP0402 & $0.5-2$ & 120 \\
\hline & Boring DP05 (Outside Drain Pit) & DP0502 & $0.5-2$ & 230 \\
\hline & Boring DP06 (Outside Drain Pit) & DP0602 & $0.5-2$ & 180 \\
\hline & \multirow{2}{*}{ Boring DP07 (Inside Drain Pit) } & DP0701 & $0.0-0.5$ & 650 \\
\hline & & DP0702 & $0.5-2$ & 450 \\
\hline & \multirow{2}{*}{ Boring DP08 (Inside Drain Pit) } & DP0801 & $0.0-0.5$ & 670 \\
\hline & & DP0802 & $0.5-2$ & 380 \\
\hline & \multirow{2}{*}{ Boring DP09 (Inside Drain Pit) } & DP0901 & $0.0-0.5$ & 430 \\
\hline & & DP0902 & $0.5-2$ & 580 \\
\hline \multirow{5}{*}{ May 2001} & Auger DPS01 & DPS01A & $0.0-0.5$ & 130 \\
\hline & Auger DPS04 & DPS04A & $0.0-0.5$ & 150 \\
\hline & Auger DPE01 & DPE01A & $0.0-0.5$ & 150 \\
\hline & Auger DPE03 & DPE03A & $0.0-0.5$ & 120 \\
\hline & Auger DPW02 & DPW02A & $0.75-1$ & 470 \\
\hline
\end{tabular}

ID = Identification 


\subsection{Basis for Use Restriction Modification}

The revised FALs associated with the TPH contamination were established based on the PALs of hazardous constituents of TPH diesel as described in Section 2.2.2. Hazardous constituents of TPH diesel were not detected in any of the samples at concentrations greater than their respective PALs (NNSA/NV, 2001c). Therefore, no contaminants are present at this site in concentrations exceeding the revised FALs, and all revised FALs were established at the PAL concentrations.

\subsection{Proposed Modification}

Remove the FFACO UR, associated fencing and postings, and inspection and maintenance requirements from this site. 


\section{References}

DOE/NV, see U.S. Department of Energy, Nevada Operations Office.

FFACO, see Federal Facility Agreement and Consent Order.

Federal Facility Agreement and Consent Order. 1996 (as amended). Agreed to by the State of Nevada; U.S. Department of Energy, Environmental Management; U.S. Department of Defense; and U.S. Department of Energy, Legacy Management.

NNSA/NSO, see U.S. Department of Energy, National Nuclear Security Administration Nevada Site Office.

NNSA/NV, see U.S. Department of Energy, National Nuclear Security Administration Nevada Operations Office.

U.S. Department of Energy, National Nuclear Security Administration Nevada Site Office. 2003b. Closure Report for Corrective Action Unit 335: Area 6 Injection Well and Drain Pit, Nevada Test Site, Nevada, Rev. 0, DOE/NV--910. June. Las Vegas, NV.

U.S. Department of Energy, National Nuclear Security Administration Nevada Site Office. 2004f. NV/YMP Radiological Control Manual, DOE/NV--11718-079, Rev. 5. Prepared by Bechtel Nevada. Las Vegas, NV.

U.S. Department of Energy, National Nuclear Security Administration Nevada Site Office. 2006c. Industrial Sites Project Establishment of Final Action Levels, Rev. 0, DOE/NV--1107. Las Vegas, NV.

U.S. Department of Energy, National Nuclear Security Administration Nevada Operations Office. 2001c. Corrective Action Decision Document for Corrective Action Unit 335: Area 6 Injection Well and Drain Pit, Nevada Test Site, Nevada, Rev. 0, DOE/NV--759. November. Las Vegas, NV.

U.S. Department of Energy, Nevada Operations Office. 2000c. Corrective Action Investigation Plan for Corrective Action Unit 335: Area 6 Injection Well and Drain Pit, Nevada Test Site, Nevada, Rev. 0, DOE/NV--663. December. Las Vegas, NV. 


\section{Library Distribution List}

\section{$\underline{\text { Copies }}$}

U.S. Department of Energy

National Nuclear Security Administration

Nevada Site Office

Technical Library

P.O. Box 98518, M/S 505

Las Vegas, NV 89193-8518

U.S. Department of Energy

Office of Scientific and Technical Information

P.O. Box 62

Oak Ridge, TN 37831-0062

Southern Nevada Public Reading Facility

c/o Nuclear Testing Archive

P.O. Box 98521, M/S 400

Las Vegas, NV 89193-8521

Manager, Northern Nevada FFACO

Public Reading Facility

c/o Nevada State Library \& Archives

100 N Stewart Street

Carson City, NV 89701-4285
1 (Uncontrolled, electronic copy)

1 (Uncontrolled, electronic copy)

2 (Uncontrolled, electronic copies)

1 (Uncontrolled, electronic copy) 